DOI: 10.21802/artm.2020.1.13.129.

УДК 612.826.33: 612.46

\title{
ОСОБЛИВОСТІ ВПЛИВУ МЕЛАТОНІНУ НА ХРОНОРИТМІЧНУ ОРГАНІЗАЦІЮ КИСЛОТОРЕГУЛЮВАЛЬНОЇ ФУНКЦІЇ НИРОК ПІД ВПЛИВОМ БЛОКАДИ СИНТЕЗУ МОНООКСИДУ НІТРОГЕНУ ЗА УМОВ ГІПОФУНКЦІЇ ШИШКОПОДІБНОЇ ЗАЛОЗИ
}

\author{
С.Б. Семененко ${ }^{1}$, І.Р. Тимофійчук ${ }^{2}$, К.В.Слободян ${ }^{3}$, В.В. Семененко ${ }^{4}$, Н.Ю. Семененко ${ }^{5}$
}

Вищий державний навчальний заклад України «Буковинський державний медичний університет», кафедра фізіології ім. Я.Д. Кіршенблата, м. Чернівиі, Україна,

${ }^{1}$ Researcher ID: 1-1015-2016, ORCID ID: 0000-0002-6124-1938,

${ }^{2}$ Researcher ID: 1-1185-2016, ORCID ID: 0000-0003-2617-9697,

e-mail: semenenko.svitlana@bsmu.edu.ua

Резюме. Про ритмічну організацію окремих функцій організму лікарям відомо давно. У здорових людей ритми фізіологічних процесів синхронізовані як між собою, так і з ритмами навколишнього середовища, що забезпечує оптимальні умови функціонування організму і $є$ ознакою здоров’я.

Мета цього дослідження полягає у вивченні особливостей впливу мелатоніну на хроноритмічну організацію кислоторегулювальної функції нирок під впливом блокади синтезу монооксиду нітрогену за умов гіпофункції шишкоподібної залози.

Матеріали і методи. Досліди провели на 72 статевозрілих нелінійних самцях білих щурів масою 0,150,18 кг. Тварин утримували в умовах віварію при сталій температурі та вологості повітря на стандартному харчовому раціоні. Контрольну групу склали тварини $(\mathrm{n}=36)$, які перебували за умов звичайного світлового режиму (12.00C:12.00T) упродовж семи діб. Досліджувану групу склали тварини (n=36), яким уводили N-нітро-Lаргінін (L-NNA) в дозі 20 мг/кг упродовж 7-ми діб за умов постійного освітлення (12.00C:12.00C) і паралельно мелатонін (MT) в дозі 0,5 мг/кг упродовж 7-ми діб.

Результати дослідження та їх обговорення. 3'ясування особливостей хроноритмічних перебудов кислоторегулювальної функції нирок за умов блокади синтезу монооксиду нітрогену (NO) і уведення МT на тлі пригніченої активності шишкоподібної залози (ШЗ) є важливим для пізнання механізмів виникнення та розвитку патологічних станів, що удосконалить лікування ниркової патології.

Висновки. Таким чином, блокада синтезу NO за умов корекції МТ наближає середньодобовий рівень екскреції іонів водню до контролю. Уведення L-NNA на тлі гіпофункції ШЗ та корекція МТ змінювало структуру хроноритмів екскреції кислот, що титруються та призвело до суттєвого підвищення даного показника і екскреції аміаку упродовж періоду спостереження.

Ключові слова: мелатонін, циркадіанний ритм, нирки, монооксид нітрогену, шишкоподібна залоза.

Вступ. Відомо, що всі живі організми володіють властивістю відчувати час. Властивість визначати час стала необхідною умовою виживання організмів [1]. Епіфіз і МТ мають загальнобіологічне значення для життєдіяльності організмів на всіх рівнях еволюційного розвитку. Медичні проблеми функціонування епіфізу зумовлюються фармакологічними властивостями МТ [2]. 3'ясуванням організації біологічних систем, ролі чинника часу у здійсненні біологічних явищ і поведінці живих систем, природи, умовами виникнення i значення біоритмів для організмів займається біоритмологія. Один із напрямів біології - хронобіологія - вивчає біоритми та механізми, що лежать в їх основі [3].

Обгрунтування дослідження. Згідно літературних джерел, великий інтерес представляють біологічні ритми з періодом близько доби, які називаються циркадіанними біоритмами. У людини багато функцій підпорядковані добовому ритму [4]. Наприклад, сон, підвищення і пониження кров'яного тиску, екскреція титрованих кислот нирками, коливання часу рефлексу, пітливість долонь та інші [5]. Біологічні ритми у людини формуються поступово в ході індивідуального розвитку. Вони підпорядковуються чинникам зовнішнього середовища, зокрема зміні дня і ночі [6]. Основним хроноритмологічним гормоном $є$ епіфізарний гормон мелатонін [7]. Проте, як часто буває у клінічній медицині, можливості мелатоніну, як лікарського засобу та внутрішньоклітинного месенджера NO, лікарі у своїй практичній діяльності використовують досить обмежено [8]. Дослідженнями А.І. Гоженко та співавт. встановлено, що патологія нирок виникає внаслідок пошкодження ниркових клубочків та/або канальців, які незалежно від етіології сприяють розвитку гострої ниркової недостатності [9]. Циркадіанний ритм аміноацидурії при хронічному гломерулонефриті досліджував Т.Д. Никула та співавт., виявивши послідовну зміну ритмів екскреції, що корелює зі стадією хронічного гломерулонефриту: від транзиторної дизритмії у початковій стадії до "дзеркального" відображення нормальних ритмів в стадії ниркової недостатності. Автор вважає, що визначення циркадіанних ритмів аміноацидурії можна використовувати для виявлення початкових порушень амінокислотного обміну i функціонального стану нирок [10]. 
У роботі розглянуто вплив блокади синтезу NO на циркадіанну організацію кислоторегулювальної функції нирок за умов гіпофункції ШЗ та корекції MT.

Мета цього дослідження полягає у вивченні особливостей впливу мелатоніну на хроноритмічну організацію кислоторегулювальної функції нирок під впливом блокади синтезу монооксиду нітрогену за умов гіпофункції шишкоподібної залози.

Матеріали і методи. Досліди провели на 72 статевозрілих нелінійних самцях білих щурів масою 0,15-0,18 кг. Тварин утримували в умовах віварію при сталій температурі та вологості повітря на стандартному харчовому раціоні. Контрольну групу склали тварини $(\mathrm{n}=36)$, які перебували за умов звичайного світлового режиму (12.00С:12.00T) упродовж семи діб. Досліджувану групу склали тварини $(\mathrm{n}=36)$, яким уводили N-нітро-L-аргінін (L-NNA) в дозі $20 \mathrm{мг/кг}$ упродовж 7-ми діб за умов постійного освітлення (12.00C:12.00C) і паралельно МТ в дозі 0,5 мг/кг упродовж 7-ми днів. На 8-у добу тваринам проводили 5\% водне навантаження підігрітою до кімнатної температури водогінною водою і досліджували параметри кислоторегулювальної функції нирок за умов форсованого діурезу.

Експерименти проводили 3 4-годинним інтервалом упродовж доби. Вивчали рівень $\mathrm{pH}$ сечі, екскрецію іонів водню, кислот, що титруються, аміаку, амонійного коефіцієнта. Результати обробляли статистично методом "Косинор-аналізу”, а також параметричними методами варіаційної статистики. Діагностика функціональних особливостей грунтувалася на основі аналізу змін характеристик мезору (середньодобового рівня), амплітуди, акрофази та форми кривої циркадіанного ритму. Отримані індивідуальні хронограми для кожної тварини групували за принципом ідентичності максимальної акрофази і розраховували методом "Косинор-аналізу” пересічні для кожної групи хронограм мезор, амплітуду і фазову структуру (за інтервалом часу між акро- та батифазою).

Всі етапи експерименту проведено 3 дотриманням основних вимог Свропейської конвенції щодо гуманного ставлення до тварин.

Отримані експериментальні дані обробляли на персональних комп'ютерах пакетом програм ЕXCE-2003 (Microsoft Corp., США). Для всіх показників розраховували значення середньої арифметичної вибірки (x), їі дисперсії і похибки середньої (Sx). Для виявлення вірогідності відмінностей результатів у дослідних і контрольних групах тварин визначали коефіцієнт Стьюдента (t), після чого визначали вірогідність відмінності вибірок (p) і довірчий інтервал середньої за таблицями розподілу Стьюдента. Вірогідними вважали значення, для яких $\mathrm{p}<0,05$.

Результати дослідження. Хроноритмічні перебудови кислоторегулювальної функції нирок у тварин, яким блокували синтез NO на фоні постійного освітлення і паралельно уводили МТ дозволяють припустити, що блокада синтезу NO за умов корекції МТ наближає середньодобовий рівень екскреції іонів водню до контролю. Однак він був вищим відносно такого у тварин, яким проводили блокаду синтезу NO на тлі фізіологічної функції ШЗ і тварин 3 гіпофункцією ШЗ (рис. 1). Акрофаза ритму припадала на 20.00 год., батифаза - на 24.00 год.

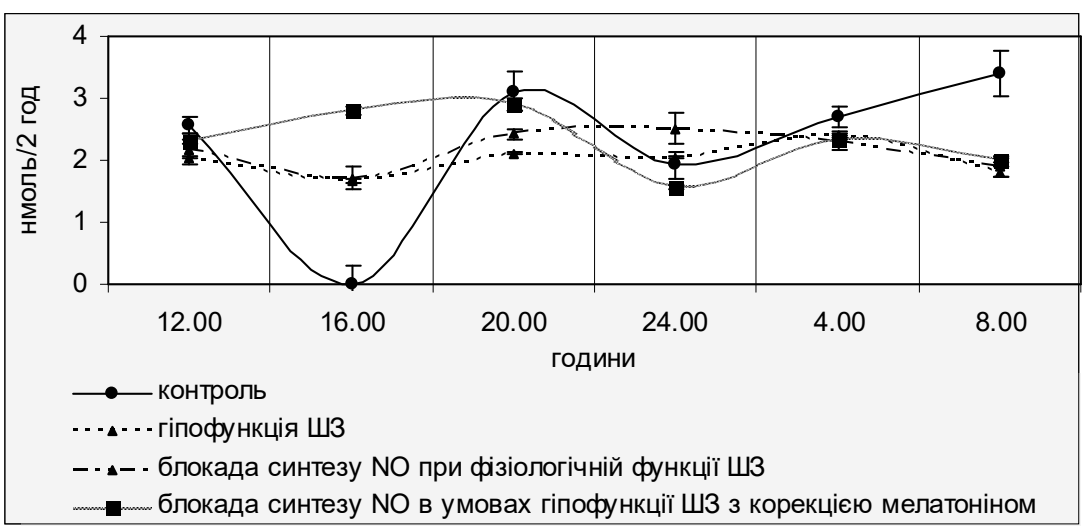

\author{
Рис. 1. Хроноритми \\ екскреції іонів водню \\ (нмоль/2год) у щурів, \\ яким проводили блокаду \\ синтезу монооксиду \\ нітрогену і уводили \\ мелатонін в умовах \\ гіпофункціїшишкоподібн \\ ої залози
}

Уведення L-NNA на тлі гіпофункції Ш3 та корекція МТ порушували структуру хроноритмів екскреції кислот, що титруються. В умовах гіпофункції ШЗ у період з 8.00 год. до 12.00 год. реєстрували зростання виведення вказаних сполук, а блокада синтезу NO за умов гіпофункції Ш3 нівелювала цей ефект. Проте блокада синтезу NO за умов гіпофункції ШЗ та уведення МТ призвели до суттєвого підвищення екскреції титрованих кислот (рис. 2).

Що стосується екскреції аміаку, то під час блокади синтезу NO на фоні гіпофункції Ш3 спо- стерігали різке підвищення екскреції вказаної сполуки, а під час блокади синтезу NO на тлі фізіологічної функції цього органу спостерігали різке зниження екскреції вказаної сполуки, а на фоні гіпофункції цього органу за умов блокади NO та уведення МТ спостерігали суттєве підвищення екскреції аміаку упродовж періоду спостереження (рис. 3). Ритм набував монотонного характеру з акрофазою о 20.00 год., батифаза припадала на 24.00 год. 


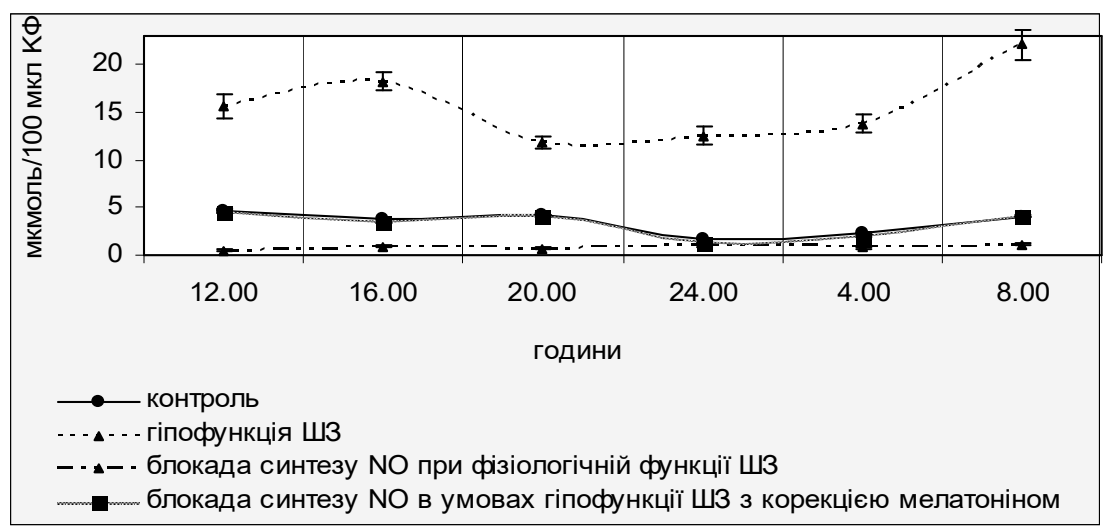

Рис. 2. Хроноритми екскреції кислот, що титруються (мкмоль/100 мкл КФ), у щурів, яким проводили блокаду синтезу монооксиду нітрогену i уводили мелатонін в умовах гіпофункції шишкоподібної залози

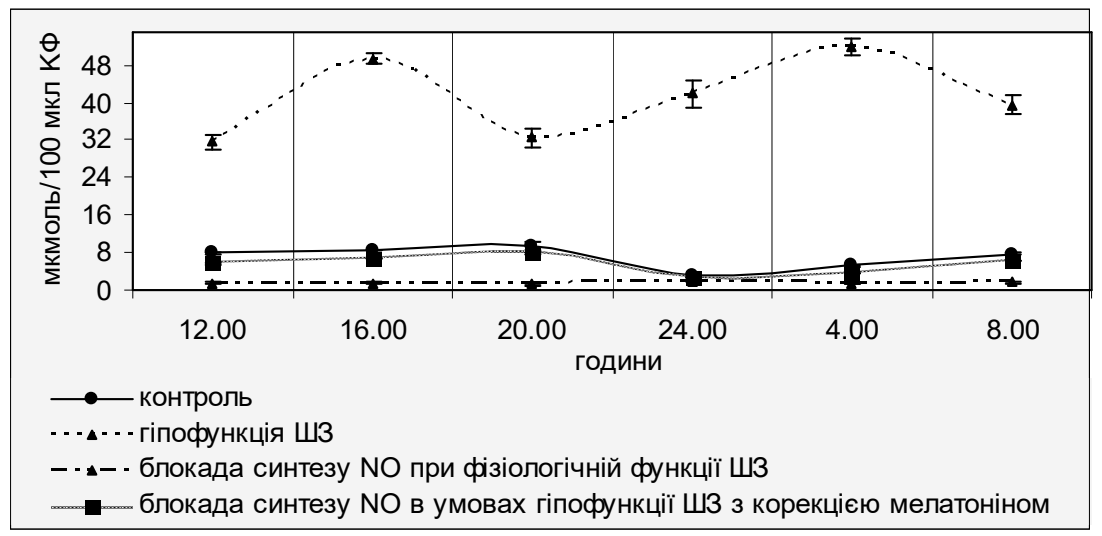

Рис. 3. Хроноритми екскреції аміаку (мкмоль/100 мкл КФ) у щурів, яким проводили блокаду синтезу монооксиду нітрогену i уводили мелатонін в умовах гіпофункції шишкоподібної залози

\section{Обговорення результатів. 3'ясування особливостей хроноритмічних перебудов} кислоторегулювальної функції нирок за умов блокади синтезу NO i уведення МТ на тлі пригніченої активності ШЗ є важливим для пізнання механізмів виникнення та розвитку патологічних станів, що надасть можливість покращити ранню діагностику, удосконалити лікування ниркової патології та своєчасно проводити профілактичні заходи. Циркадіанний ритм аміноацидурії при хронічному гломерулонефриті (ХГН) досліджував Т.Д. Никула та співавт., виявивши послідовну зміну ритмів екскреції, що корелює зі стадією хронічного гломерулонефриту: від транзиторної дизритмії у початковій стадії до "дзеркального" відображення нормальних ритмів в стадії ниркової недостатності. Автор вважає, що визначення циркадіанних ритмів аміноацидурії можна використовувати для виявлення початкових порушень процесів, які забезпечують гомеостатичні функції нирок при їх патології, можуть призводити до тяжких і нерідко фатальних наслідків. Особливо важливе значення мають функціональні підходи у діагностиці і патології нирок, пов'язані з порушенням водно-сольового і кислотно-основного гомеостазу [10]. Як зазначає A.I. Гоженко та співавт., частина нефронів може гинути в результаті прямої дії етіологічних чинників, а зменшення кількості та ушкодження діючих нефронів $є$ патогенетичною основою порушення ниркових функцій, що сприяє розвитку хронічної ниркової недостатності [9].

\section{Висновки:}

1. За умов L-NNA блокади синтезу монооксиду нітрогену і уведення мелатоніну в умовах гіпофункції шишкоподібної залози спостерігали хроноритмічні перебудови архітектоніки та фазової структури ритмів більшості показників кислоторегулювальної функції нирок.

2. Виявлено істотне підвищення мезору та амплітуди ритму рН порівняно з показниками контрольних тварин.

3. Досліджено наближення середньодобового рівня ритму амонійного коефіцієнту, екскреції кислот, що титруються та аміаку у досліджувані періоди спостережень до показника контрольних тварин.

\section{References:}

1. Vinod C, Jagota A. Melatonin reduces traumatic brain injury-induced oxidative stress in the cerebral cortex and blood of rats. Neural Regen. Res. 2016; 9(11):1112-1116.

2. Kaladze NN, Slobodian EY, Hovdaliuk AL. Эpyfyzarnыi hormon melatonyn y khronycheskaia bolezn pochek (obzor lyteraturb y sobstvennoho yssledovanyia). Zhurnal «Zdorovia dytyny». 2015; 2(61):183-185.

3. Manchester LC, Coto-Montes A, Boga JA, Andersen LP, Zhou Z, Galano A, et al. Melatonin: an ancient molecule that makes oxygen metabolically tolerable. J. Pineal Res. 2015; 59(4):403-19.

4. Bedont JL, Newman EA, Blackshaw S. Pattering, specification, and differentiation in the developing hypothalamus. Wiley Interdiscip Rev Dev Biol. 2015; 4(5):445-68.

5. Semenenko SB, Karatieieva SU, Bakun OV, Slobodian KV, Peryzhniak AI. Circadian characteristic of kidney excretory function influenced by nitrogen 
monoxide synthesis blockade under conditions of pineal gland normal with peculiarities of melatonin effect. Wiadomosci Lekarskie. 2018; LXXI (7):13311335.

6. Semenenko SB, Karatieieva SU, Slobodian KV, Bacun OV, Yurkiv OI. Peculiairities of the influence nitrogen monoxides synthesis blockade on circadian organization of kidney acid-regulating function under conditions of pineal gland hyperfunction. Wiadomosci Lekarskie. 2018; LXXI (9):1681-1684.

7. Zaichenko HV, Horchakova NO, Klymenko OV, Yakovleva NIu, Sinitsyna OS. Melatonin yak potentsialnyi kardioprotektor. Eksperymentalno-klinichnyi analiz efektyvnosti. Visnyk problem biolohii i medytsyny. 2019; 2 (1/150):2-6.2.

8. Sadlyak OV, Kolishetska MA, Baida ML, MusijSementsiv RhG, Sementsiv NG, Lesyk RB. Nitric Oxide as the main multifimetional regulator of immunocomponent and endothelial cells. Biopolymers and Cell. 2017; 33(5):323-334.

9. Hozhenko AI, Kravchuk AV, Nykytenko OP, Moscalenko OM, Sirman VM. Funktsionalnyi nyrkovyi rezerv. Monohrafiia. 2015; Odesa: 176-177.

10. Nycula TD, Furleta VV. Vplyv antyhomotoksychnoi terapii na funktsionalnyi stan systemy travlennia $u$ kvorykh na khronichnyi piielonefryt. Actual Problems of Nephrology. 2015; (21): 84-86.

\section{УДК 612.826.33: 612.46 \\ ОСОБЕННОСТИ ВЛИЯНИЯ МЕЛАТОНИНА НА ХРОНОРИТМИЧЕСКУЮ ОРГАНИЗАЦИЮ КИСЛОТОРЕГУЛИРУЮЩЕЙ ФУНКЦИИ ПОЧЕК ПОД ВЛИЯНИЕМ БЛОКАДЫ СИНТЕЗА МОНООКСИДА НИТРОГЕНА ПРИ УСЛОВИИ ГИПОФУНКЦИИ ШИШКОВИДНОЙ ЖЕЛЕЗЫ}

С.Б. Семененко ${ }^{1}$, И.Р. Тимофийчук ${ }^{2}$, К.В.Слободян ${ }^{3}$, В.В. Семененко ${ }^{4}$, Н.Ю. Семененко

Выстее государственное учебное заведение Украины «Буковинский государственный медииинский

Университет», кафедра физиологии им.

Я.Д. Киршенблата, г. Черновиы, Украина,

${ }^{1}$ Researcher ID: 1-1015-2016,

ORCID ID: 0000-0002-6124-1938,

${ }^{2}$ Researcher ID: 1-1185-2016,

ORCID ID: 0000-0003-2617-9697,

e-mail:semenenko.svitlana@bsmu.edu.ua

Резюме. О ритмической организации отдельных функций организма врачам известно давно. В здоровых людей ритмы физиологических процессов синхронизированные между собой, что обеспечивает оптимальные условия функционирования организма.

Цель этого исследования заключается в изучении особенностей влияния мелатонина на хроноритмическую организацию кислоторегулирующей функции почек под влиянием блокады синтеза монооксида нитрогена при условии гипофункции шишковидной железы.
Материалы и методы. Исследования провели на 72 половозрелых нелинейных самцах белых крыс весом 0,15-0,18 кг. Животных содержали в условиях вивария при постоянной температуре и влажности воздуха на стандартном пищевом рационе. Контрольную группу составили животные $(\mathrm{n}=36)$, которые находились в условиях обычного светлового режима (12.00С:12.00T) на протяжении семи суток. Исследуемую группу составили животные $(\mathrm{n}=36)$, которым вводили N-нитро-L-аргинин (L-NNA) в дозе 20 мг/кг на протяжении 7-ми суток при условии постоянного осветления $(12.00 \mathrm{C}: 12.00 \mathrm{C})$ и параллельно мелатонин (МТ) в дозе 0,5 мг/кг на протяжении 7-ми суток.

Результаты исследования и их обсуждение. Выяснение особенностей хроноритмичних перестроек кислоторегулювальнои функции почек в условиях блокады синтеза оксида азота (NO) и введения МТ на фоне подавленной активности шишковидной железы (ШЗ) является важным для познания механизмов возникновения и развития патологических состояний, усовершенствует лечения почечной патологии.

Выводы. Таким образом, блокада синтеза NO в условиях коррекции МТ приближает среднесуточный уровень экскреции ионов водорода к контролю. Введение L-NNA на фоне гипофункции Ш3 и коррекция МТ нарушало структуру хроноритмов экскреции титрируемых кислот и привело к существенному повышению данного показателя и экскреции аммиака в течение периода наблюдения.

Ключевые слова: мелатонин, циркадианный ритм, почки, монооксид нитрогена, шишковидная железа.

\section{UDC 612.826.33: 612.46 \\ THE FEATURES OF MELATONIN INFLUENCE ON THE CHRONORHYTHMIC ORGANIZATION OF THE ACID-REGULATING FUNCTION OF THE KIDNEY UNDER THE INFLUENCE OF THE BLOCKADE OF NITROGEN MONOXIDE SYNTHESIS UNDER THE CONDITION OF THE PINEAL GLAND HYPOFUNCTION}

S.B. Semenenko ${ }^{1}$, I.R. Timofiychuk ${ }^{2}$, K.V. Slobodian ${ }^{3}$, V.V. Semenenko ${ }^{4}$, N.Yu. Semenenko ${ }^{5}$

Higher State Educational Establishment of Ukraine "Bukovyna State Medical University», department of Physiology named after Ya.D. Kirshenblat,

Chernivtsi, Ukraine,

${ }^{I}$ Researcher ID: 1-1015-2016,

ORCID ID: 0000-0002-6124-1938,

${ }^{2}$ Researcher ID: 1-1501-2016,

ORCID ID: 0000-0001-5601-2244,

e-mail: semenenko.svitlana@bsmu.edu.ua

Abstract. The doctors have known about the rhythmic organization of individual body functions for a long time. Rhythm is considered as the decapitating ability of living matter at all levels of the organization, and 
the study of the rhythms of the functioning of various body systems, factors that affect their formation is of immediate interest to modern biology and medicine.

The purpose of this study is to evaluate the effects of melatonin on the chronorhythmic organization of the acid-regulating function of the kidneys under the influence of a blockade of nitrogen monoxide synthesis under conditions of hypofunction of the pineal gland.

Materials and methods. Studies were performed on 72 sexually mature non-linear male white rats weighing $0.15-0.18 \mathrm{~kg}$. The animals were kept in vivarium at a constant temperature and humidity in a standard diet. The control group consisted of animals $(n=36)$, which were under normal light conditions (12.00L: 12.00D) for seven days. The study group consisted of animals $(n=36)$, which were injected with N-nitro-Larginine (L-NNA) at a dose of $20 \mathrm{mg} / \mathrm{kg}$ for 7 days under the condition of constant clarification $(12.00 \mathrm{~L}: 12.00 \mathrm{~L})$ and parallel to melatonin (MT) at a dose of $0.5 \mathrm{mg} / \mathrm{kg}$ for 7 days. On the 8th day, the animals were treated with a $5 \%$ water load of running water heated to room temperature and the parameters of acid-regulating function of the kidneys were examined under the condition of forced diuresis.

The experiments were carried out at 4-hour intervals throughout the day. We studied the $\mathrm{pH}$ level of urine, the excretion of hydrogen ions, the acids that are titrated, ammonia, and the ammonium coefficient. The results were processed statistically by the method of "Cosinor analysis", as well as a parametric method of variation statistics. Diagnostics of functional features was based on the analysis of changes in the characteristics of the mesor (daily average level), amplitude, acrophase, and the shape of the circadian rhythm curve.

The obtained individual chronograms for each animal were grouped according to the principle of maxi- mum acrophase identity and calculated by the "Cosinor analysis" method, the mesor, amplitude, and phase structure intersecting for each group of chronograms (according to the time interval between acro- and bathyphase).

All stages of the experiment were carried out in compliance with the basic requirements of the European Convention for the Humane Treatment of Animals

Results of the research and their discussion. The elucidation of the features of chronorhythmic rearrangements of the acid-regulating function of the kidneys under the condition of nitrogen monoxide (NO) synthesis and the introduction of MT against the background of inhibition of the activity of the pineal gland (PG) is important for understanding the mechanisms of the onset and development of pathological conditions, which makes it possible to improve early diagnosis, improve treatment of renal pathology, and timely carry out preventive measures.

Conclusions. Thus, under the condition of LNNA blockade of the synthesis of nitrogen monoxide and the introduction of melatonin under conditions of hypofunction of the pineal gland, chronorhythmic rearrangements of the architectonics and phase structure of the rhythms of most indicators of acid-regulating function of the kidneys were observed.

Thus, blockade of synthesis NO under conditions of MT correction brings the average daily excretion level of hydrogen ions to the control. The introduction of L-NNA against the background of hypofunction PG, and the correction of MT changed the structure of the excretion chronorhythms of the titrated acids, and led to a significant increase in this indicator, and ammonia excretion during the observation period.

Keywords: melatonin, circadian rhythm, kidneys, nitrogen monoxide, pineal gland. 